different approach to its perennial battle with Congress over the National Institutes of Health (NIH).

In past years, the tactic has been to ask for no increase for NIH in the knowledge that Congress in its rapture with that most popular of scientific agencies will add too much anyway. The administration has become increasingly concerned, however, that Congress's enthusiasm tends to be channelled into advocacy for narrow, disease-specific research, a tendency that threatens NIH's traditional freedom to support valuable but less glamorous basic research. "The "disease-of-the-month club' syndrome is no longer a joke", Keyworth said recently.

This year, the administration is proposing to give NIH an additional $\$ 102$ million, but specifically for areas of basic research that it believes have been neglected, such as neurobiology. Keyworth said he hopes that this proposal will "open a dialogue" with Congress and will give the administration a chance to air its views on the importance of basic research in the life sciences - particularly its role in underpinning US competitiveness in

biotechnology.

The Environmental Protection Agency, which in past years has felt the full weight of the administration's budget-cutting, is in for a modest increase this year in research funding. The news may not cheer the environmental lobby, however, as much of the new money will go for further studies of acid rain at a time when many including a panel that Keyworth himself assembled - have concluded that enough studies have already been done to support regulatory action, a step at which Reagan still baulks.

The National Oceanic and Atmospheric Administration (NOAA), the National Bureau of Standards (NBS) and the US Geological Survey are all in for major cuts in support for research and development on the principle that much of their research belongs in the private sector.

Particularly hard hit is NOAA, which is to lose a full one-third of its $\$ 242$ million research and development budget. And NBS's fire and building research centres are once again under threat of closure.

Stephen Budiansky

\title{
Agricultural research
}

\section{Towards grant competition}

\section{Washington}

THE US agricultural system, which has been repeatedly criticized for fostering mediocrity and neglecting basic science, is in for a major shake-up if the Reagan Administration has its way. The 1985 budget proposal would triple the size of the small programme of competitive grants for agricultural research, bringing it up to $\$ 50$ million, the maximum level currently authorized by law. The bulk of the new money would be reserved for basic research related to biotechnology.

Under the administration's proposal, most of the federal funds for sponsored research in agriculture would continue to be distributed to the country's land-grant colleges according to a state-by-state formula not involving peer review. But by rapidly expanding the competitive grants programme beyond its token level of $\$ 17$ million, the administration hopes to effect a major change in the way agricultural research is carried out. The expanded programme is expected to attract researchers at non-land-grant universities (among them the $I$ ading US basic research centres, such as Harvard and Stanford Universities) which are shut out from the formula-fund system. It may also bring some scientific rigour, by way of peer review, to a system often accused of drifting more and more to applied research of dubious scientific merit.

The new money, $£ 33$ million, is to come in part from an overall increase in the research budget of the Department of Agriculture (USDA) and in part from the phasing-out of the so-called "special grants", funds earmarked, usually by Congress, for specific projects.

Congress has baulked at past efforts to expand the competitive grants programme, which the smaller land-grant colleges in particular see as a threat to their assured support from the formula funds. This time things may be different. Many of the larger and scientifically more competitive landgrant institutions have broken ranks and have declared themselves in favour of an enlarged competitive grants programme. And both Secretary of Agriculture John Block and presidential science adviser George Keyworth have taken a personal interest in the programme.

Besides the new effort in biotechnology (which would receive $\$ 28.5$ million), the administration's proposal would establish a small effort in animal sciences (\$4.5 million); existing components in plant sciences (\$15 million) and human nutrition ( $\$ 2$ million) would continue. Approximately one-quarter of the competitive research funds would be expected to support graduate research assistants working under project grants.

The National Science Foundation's plant biology programme, which has traditionally taken up the slack in basic plant research, is also due for an increase under the President's budget - a 16 per cent rise, to $\$ 58$ million.

The USDA formula funding would grow by 2 per cent next year; and Department of Agriculture's own in-house research arm, the Agricultural Research Service, would receive a 3 per cent increase. Beltsville is not to be frozen out.

\section{Space science Panel's advice
ignored}

Washington

SPACE scientists are unlikely to give more than two cheers for the 1985 budget request for the National Aeronautics and Space Administration (NASA). The agency's basic research receives a hefty increase to $\$ 828$ million and three important new projects - the Mars Geoscience/Climatology Orbiter, the Upper Atmosphere Research Satellite and the Scatterometer experiment - have been given the go-ahead. But NASA has unexpectedly baulked at a plan to inject urgently needed new funds into university research groups.

The plan, devised jointly last year by university space scientists and NASA officials, carried the imprimatur of Frank McDonald, NASA's chief scientist. Yet neither of its chief recommendations found

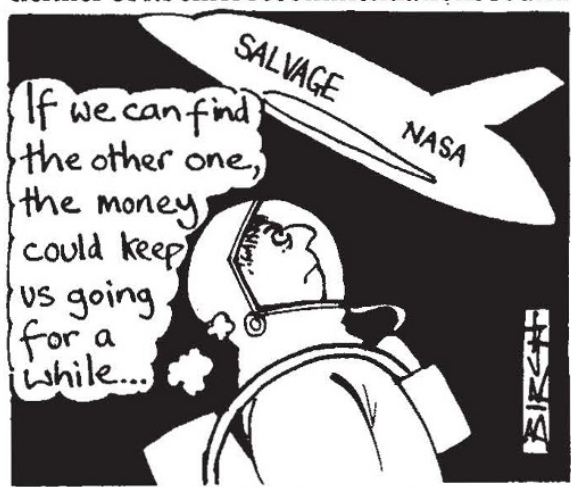

its way into the 1985 budget. One was to spend $\$ 11$ million extra a year for five years to buy new equipment for universities chiefly oscilloscopes, spectral analysers, computers, micro-ion probes and gas analysers. The other was to resurrect the NASA graduate fellowships that helped build up university space science in the 1960s.

Worse still, the budget contains no increase for basic research grants for university space science. Support for physics and astronomy is held at the same level as last year, while the amount for planetary science is reduced. Only one important recommendation of the McDonald report - more money to analyse mission data has been incorporated in the 1985 request. Funds for space shuttle operations are due to rise from $\$ 81$ million to $\$ 105$ million, but that is not expected to be enough to make shuttle science significantly cheaper or faster; since 1978 there has been a backlog of experiments waiting to fly.

NASA's overall budget increase is a scant $\$ 274$ million, or 4 per cent. That is enough, however, to keep alive major projects such as the Space Telescope (now renamed the Hubble Space Telescope), the Galileo mission to Jupiter and the Venus Radar Mapper. For 1985 only $\$ 150$ million is allocated for research on the proposed space station.

Peter David 